\title{
Pengembangan Model Pelatihan Berbasis Aplikasi Quiz Creator untuk Meningkatkan Kreativitas Guru
}

\author{
Tiya Anggita ${ }^{1 *}$, Abdullah Idi ${ }^{1}$, Muhammad Fauzi ${ }^{1}$ \\ ${ }^{1}$ UIN Raden Fatah Palembang, Indonesia
}

\begin{abstract}
Abstrak: Penelitian ini bertujuan untuk mengetahui dan menganalisis model pelatihan berbasis aplikasi wondershare quiz creator efektif dalam meningkatkan kreativitas guru di Madrasah Aliyah Patra Mandiri Palembang. Penelitian ini adalah penelitian pengembangan. Modifikasi model yang digunakan adalah design ADDIE (Analysis, Design, Development, Implementation, Evaluation), Martin Tessmer dan Model Kirkpatrick. Penelitian ini menunjukkan bahwa terdapat perbedaan yang signifikan antara sebelum dan sesudah guru mengikuti pelatihan berbasis aplikasi wondershare quiz creator. Dengan demikian, model pelatihan berbasis aplikasi wondershare quiz creator efektif untuk meningkatkan kreativitas guru Madrasah Aliyah Patra Mandiri Palembang untuk membuat soal interaktif.
\end{abstract}

Kata Kunci: quiz creator, kreativitas guru, soal interaktif

\begin{abstract}
This study aims to identify and analyze the wondershare quiz creator application-based training model that is effective in increasing teacher creativity at Madrasah Aliyah Patra Mandiri Palembang. This research is development research. Modification of the model used is ADDIE design (Analysis, Design, Development, Implementation, Evaluation), Martin Tessmer and Kirkpatrick Model. This study shows that there is a significant difference between before and after the teacher participates in the Wondershare quiz creator application-based training. Thus, the Wondershare quiz creator application-based training model is effective in increasing the creativity of Madrasah Aliyah Patra Mandiri Palembang teachers to create interactive questions.
\end{abstract}

Keywords: quiz creator, teacher creativity, interactive question

\section{Pendahuluan}

Evaluation tools in learning is a tool used to measure an object of measurement or collect data about a variable. In education the instrument used to measure undergraduates learning achievement, factors have a relationship or influence their learning outcomes, the success of the teaching and learning process, and the success of achieving a program (Oliver et al., 2008). Evaluasi hasil belajar siswa dilakukan untuk memantau proses, kemajuan, dan perbaikan hasil belajar secara berkesinambungan (Penyusun, 2003). Pengumpulan informasi tentang keberhasilan pembelajaran siswa meliputi kompetensi sikap spiritual, kompetensi sikap sosial, kompetensi pengetahuan, dan kompetensi keterampilan yang dilakukan secara terencana dan sistematis, selama dan setelah proses pembelajaran (Permendikbud, 2014).

Perkembangan zaman teknologi saat ini, evaluasi mengalami perubahan yang meningkat

\footnotetext{
${ }^{*}$ Corresponding Author: Tiya Anggita (tiyaanggita.ta@gmail.com). UIN Raden Fatah Palembang, Indonesia
} 
seperti tes penerimaan pegawai negeri sipil (CPNS) dengan sistem CAT (Computer Assisted Test), tes kelulusan siswa yaitu UNBK (Ujian Nasional Berbasis Komputer) dan tes TOEFL (Test of English as a Foreign Language) yaitu dengan CBT (Computer Based Test). Dengan perubahan sistem tersebut, pendidik perlu mempersiapkan siswa yang mampu menghadapi tantangan zaman agar mampu berpikir kritis, lebih kreatif (van den Berg, 2004) dan mampu berkolaborasi, berkomunikasi dengan baik dengan memahami bahasa komputer (Janssen et al., 2019).

Era Generasi Milenial, kompetensi guru senantiasa di-upgrade. Jika tidak, wawasan guru akan tertinggal dengan siswa. Salah satu kompetensi inti guru adalah menyelenggarakan penilaian dan evaluasi hasil belajar (Penyusun, 2007) dan menerangkan bahwa pendidik menilai hasil pembelajaran (Penyusun, 2003). Guru menyelenggarakan penilaian dan evaluasi hasil belajar yang mencakup ulangan harian, ulangan tengah semester, ujian dan tes masih bersifat tradisional yaitu menggunakan pensil dan kertas. Hal ini menghambat proses penilaian pembelajaran dan guru mengalami kerepotan mengoreksi soalsoal siswa yang serta memerlukan waktu lebih untuk mengoreksi lembar jawaban.

Rentannya siswa melakukan kecurangan saat pelaksanaan ujian/ulangan/kuis/tes membuat suasa ujian tidak kondusif adalah suatu masalah yang berkaitan dengan sistem evaluasi pembelajaran yang kurang baik. Oleh karena itu, diperlukan kreativitas dan gagasan baru bagi guru untuk mendesain evaluasi interaktif (kuis, ujian, ulangan, soal) secara menarik. Kreativitas yang dimaksud adalah kemampuan guru dalam memilih metode, pendekatan, dan sistem evaluasi yang tepat dalam penyajian (Meryansumayeka \& Aisyah, 2016). Guru yang kreatif memiliki tugas merencanakan dan melaksanakan proses pembelajaran, menilai hasil pembelajaran, melakukan pembimbingan dan pelatihan (Penyusun, 2003).

Sistem evaluasi yang kreatif, menyenangkan mendorong menentukan strategi mengajar yang tepat dan memotivasi siswa untuk belajar lebih baik. Sistem evaluasi untuk memudahkan guru melakukan penilaian hasil belajar adalah dengan bantuan komputer yaitu software atau aplikasi tertentu. Aplikasi yang digunakan untuk membuat soal interaktif adalah Quiz egg, Quiz Maker dan Exam View (Microsoft) (Anundiati \& Fauzi, 2015). Selain itu, aplikasi lain seperti Flash, Hot Potatoes, Quiz Faber, Viewlet Quiz, Web Quiz, dan Wondershare quiz creator.

Sistem evaluasi yang kreatif dan menyenangkan untuk guru adalah aplikasi wondershare quiz creator. Apa yang dimaksud dengan Wondershare quiz creator? Wondershare quiz creator is a powerful quiz maker that lets trainers and educators create professional Flashbased quizzes and surveys with multimedia (www.wondershare.com). Students can access the quiz online or offline. The various quizzes type is true or False, Multiple Choice (Single Answer), Multiple Response (Multiple Answers), Fill in the Blank, Matching, Sequence, Word Bank, Click Map, Short Essay, etc (Siti \& Paulus, 2019). Penelitian ini memilih aplikasi wondershare quiz creator karena aplikasi ini tampilannya mirip dengan Microsoft Word sehingga memudahkan guru untuk mempelajari aplikasi sistem evaluasi. Some of the facilities available in Wondershare quiz creator, apart from the ease of use (user friendly) questions generated, among which a) Facilities feedback (feed-back) based on the responses/answers from the test participants; b) Facilities displayed the test results/scores and the steps that will be followed participants based test response/the answer is entered; c) Facility changed the text and the language on the button and label 
accordance with the manufacturer about the desire; d) Facilities included sound and color in a matter of about liking makers, and; e) Hyperlink facility, i.e. send results/scores test to email or LMS; f) Facilities random item construction; g) Security facilities with User account/password, dan h) Facilities that displayed settings could be modified, etc (Sangkala \& ul Haq, 2019).

Mengingat pentingnya aplikasi quiz creator ini, maka perlu dilakukan sosialisasi, penyuluhan dan pelatihan penggunaan aplikasi komputer quiz creator sebagai salah satu solusi guru melakukan penilaian autentik kepada anak didiknya. Berdasarkan penelitian lapangan (preliminary research) melalui kegiatan observasi dan wawancara, ada beberapa permasalahan di antaranya kegiatan evaluasi yang dilakukan guru masih bersifat konvensional (menggunakan kertas dan pensil) yang banyak menghabiskan waktu dan biaya; motivasi guru dalam melakukan inovasi kegiatan evaluasi berbasis komputer masih kurang; dan disiplin guru lemah karena tidak merasa terpacu untuk menciptakan produk yang baru.

\section{Metode}

Jenis penelitian ini adalah penelitian pengembangan pengembangan (development research/DR). Metode difokuskan pada dua tahap yaitu tahap preliminary dan tahap formative evaluation (Teori Tessmer). Tahap preliminary, menentukan tempat dan subjek, mempersiapkan jadwal pelatihan, media komputer di laboratorium dan prosedur kerja sama dengan pihak sekolah. Sedangkan pada tahap formative evaluation merupakan tahap uji coba produk yang dikembangkan oleh teori Tessmer yaitu Self Evaluation (evaluasi mandiri), Expert Review (validasi ahli), one to one evaluation (evaluasi kepada kepala sekolah dan operator), small grup evaluation (uji coba kelompok kecil dengan 5 orang guru) dan field test (uji coba kelompok besar dengan 20 orang guru).

Penelitian ini menggunakan modifikasi model design ADDIE, Martin Tessmer dan Model Kirkpatrick. Model Kirkpatrick adalah model evaluasi program yang khusus diciptakan untuk mengetahui keberhasilan pelaksanaan diklat (pendidikan dan pelatihan). Langkah-langkah model tersebut adalah (1) Analisis Masalah \& Kebutuhan, (2) design produk, (3) expert review, (4) development, (5) one to one evaluation, (6) small goup evaluation, (7) field test, dan (8) evaluation (reaction, learning and results).

Analisis model pelatihan menggunakan pendekatan deskriptif kualitatif dengan memperhatikan Analisis reduksi data yang menggolongkan, mengarahkan, membuang yang tidak perlu, penyajian data, sekumpulan informasi yang tersusun dan menarik kesimpulan/verifikasi. Analisis data validasi diperoleh dari hasil validasi produk berupa data deskriptif sesuai dengan prosedur pengembangan produk. CD hasil produk ini divalidasi oleh ahli materi dan ahli media. Data validasi berupa kritik dan saran kemudian dicermati serta dipilih sebagai acuan perbaikan produk. Kepraktisan atau praktikabilitas merupakan suatu instrumen yang dapat digunakan berulang-ulang jelas sangat memenuhi faktor kehematan, praktis dan mudah penggunaanya. Untuk menganalisis data kepraktisan small group evaluation menggunakan skal Guttaman. Sedangkan analisis data uji efektifitas pada field test menggunakan data analitik dengan desain penelitian "One-Group Pretest-Posttest Design" atau desain penelitian (before-after).

\section{Hasil dan Pembahasan}

Data validasi diperoleh dari lembar validasi ahli media dan ahli materi. Lembar validasi 
digunakan untuk mengetahui kelayakan model pelatihan aplikasi berbasis quiz creator. Dalam penelitian ini, validator ahli materi dan ahli media terdiri dari dosen UIN Raden Fatah Palembang

Tabel 1. Penilaian Hasil Validasi Ahli Media

\begin{tabular}{|c|c|c|c|c|}
\hline $\begin{array}{l}\mathbf{N} \\
\mathbf{o}\end{array}$ & $\begin{array}{c}\text { Aspek } \\
\text { Penilaia } \\
\text { n }\end{array}$ & Indikator & Skor & $\begin{array}{l}\text { Rata- } \\
\text { rata }\end{array}$ \\
\hline \multirow{5}{*}{1} & \multirow{5}{*}{$\begin{array}{l}\text { Audio } \\
\text { Visual, } \\
\text { Video }\end{array}$} & $\begin{array}{l}\text { Pemilihan musik sesuai dengan materi yang } \\
\text { disajikan dan jelas }\end{array}$ & 3 & \multirow{5}{*}{3,4} \\
\hline & & $\begin{array}{l}\text { Pemilihan gambar menarik dan sesuai } \\
\text { dengan materi }\end{array}$ & 4 & \\
\hline & & Animasi sesuai dengan materi & 3 & \\
\hline & & $\begin{array}{l}\text { Penyajian percakapan/ video interaktif } \\
\text { menarik, sesuai materi }\end{array}$ & 3 & \\
\hline & & $\begin{array}{l}\text { Penggunaan petunjuk, bahasa, kata yang } \\
\text { mudah dimengerti pengguna }\end{array}$ & 4 & \\
\hline \multirow{5}{*}{2} & \multirow{5}{*}{ Desain } & Tampilan media menarik & 4 & \multirow{5}{*}{4,2} \\
\hline & & $\begin{array}{l}\text { Media dapat digunakan sebagai alternatif } \\
\text { media pembelajaran }\end{array}$ & 3 & \\
\hline & & Media mudah, aman untuk digunakan & 5 & \\
\hline & & $\begin{array}{l}\text { Media bersifat mudah disimpan dalam } \\
\text { bentuk data (CD/Flash disk) dan bisa } \\
\text { diperbanyak }\end{array}$ & 5 & \\
\hline & & Kejelasan petunjuk penggunaan & 4 & \\
\hline \multirow{5}{*}{3} & \multirow{5}{*}{$\begin{array}{c}\text { Pewarna } \\
\text { an }\end{array}$} & Kombinasi warna media menarik & 4 & \multirow{5}{*}{4} \\
\hline & & Warna tidak menggangu materi & 4 & \\
\hline & & Transisi warna tombol tepat & 4 & \\
\hline & & Pewarnaan backround tepat & 4 & \\
\hline & & $\begin{array}{l}\text { Warna ilustrasi sesuai degan kenyataan } \\
\text { (natural) dengan kombinasi menarik }\end{array}$ & 4 & \\
\hline \multirow{5}{*}{4} & \multirow{6}{*}{ Grafis } & $\begin{array}{l}\text { Penyajian materi pada media jelas dan } \\
\text { mudah dipahami }\end{array}$ & 3 & \multirow{6}{*}{4} \\
\hline & & Pemilihan jenis huruf yang tepat & 4 & \\
\hline & & Ketepatan pemilihan background & 4 & \\
\hline & & Kualitas ilustrasi serasi dalam satu media & 4 & \\
\hline & & $\begin{array}{l}\text { Ukuran unsur-unsur tata letak media (Judul, } \\
\text { tema, ilustrasi, tombol) selaras }\end{array}$ & 5 & \\
\hline & & Total Skor & 78 & \\
\hline
\end{tabular}

Validasi ahli media dilakukan oleh Fuad Abdul Rachman. Berdasarkan data pada Tabel tersebut maka dapat dihitung persentase penilaian oleh ahli media.

Tingkat kevalidan $=\frac{\text { Skor } \text { Total }}{\text { Skor Maksimal }} \times 100 \%=$ $78 \%$

Tabel interpretasi data validitas media: $70 \%$ - 89\% Valid (dapat digunakan dengan revisi kecil). Saran ahli materi adalah pelaksanaan inti harus lebih diperjelas teknik, metode, model pelaksanaan pelatihan. Media pembelajaran harus relevan dengan materi siswa sesuai dengan kurikulum. Buat proposal pelatihan kerja sama dengan sekolah.

Tabel 2. Penilaian Hasil Validasi Ahli Materi/ Manajemen/Pedagogik

\begin{tabular}{|c|c|c|c|c|}
\hline $\begin{array}{l}\mathbf{N} \\
\mathbf{o}\end{array}$ & $\begin{array}{c}\text { Aspek } \\
\text { Penilaian }\end{array}$ & Indikator & Skor & $\begin{array}{l}\text { Rata- } \\
\text { rata }\end{array}$ \\
\hline \multirow{4}{*}{1} & \multirow{4}{*}{ Isi Materi } & $\begin{array}{l}\text { Isi Materi memiliki konsep yang benar dan } \\
\text { tepat }\end{array}$ & 4 & \multirow{4}{*}{4} \\
\hline & & $\begin{array}{l}\text { Isi Materi sesuai dengan Standart } \\
\text { Kompetensi }\end{array}$ & 4 & \\
\hline & & Isi Materi sesuai dengan kompetensi Dasar & 4 & \\
\hline & & $\begin{array}{l}\text { Isi Materi sesuai dengan Tujuan } \\
\text { Pembelajaran }\end{array}$ & 4 & \\
\hline \multirow{6}{*}{$\begin{array}{l}2 \\
.\end{array}$} & \multirow{6}{*}{$\begin{array}{c}\text { Manajeme } \\
\mathrm{n} \\
\text { Pelatihan }\end{array}$} & $\begin{array}{l}\text { Kejelasan, metode, perencanaan dan model } \\
\text { Manajemen Pelatihan Guru }\end{array}$ & 4 & \multirow{6}{*}{4,3} \\
\hline & & $\begin{array}{l}\text { Tahap Persiapan administratif (analisis) } \\
\text { sudah tepat }\end{array}$ & 5 & \\
\hline & & Tahap persiapan design produk sudah tepat & 5 & \\
\hline & & $\begin{array}{l}\text { Tahapan Pengembangan Program sudah } \\
\text { tepat }\end{array}$ & 5 & \\
\hline & & Tahap Pelaksanaan kegiatan sudah tepat & 3 & \\
\hline & & Tahap Evaluasi Kegiatan sudah tepat & 4 & \\
\hline \multirow{4}{*}{3} & \multirow{4}{*}{$\begin{array}{l}\text { Fasilitas } \\
\text { pelatihan }\end{array}$} & Kesesuaian Buku Pedoman bagi Peserta & 4 & \multirow{4}{*}{4,25} \\
\hline & & Kesesuaian Buku Pedoman bagi instruktur & 5 & \\
\hline & & $\begin{array}{l}\text { Ketersediaan komputer, co-card, sertifikat } \\
\text { yang baik }\end{array}$ & 4 & \\
\hline & & $\begin{array}{l}\text { kemudahan contoh-contoh gambar untuk } \\
\text { pelatihan }\end{array}$ & 4 & \\
\hline \multirow{3}{*}{$\begin{array}{l}4 \\
.\end{array}$} & \multirow{3}{*}{$\begin{array}{c}\text { Kurikulu } \\
\mathrm{m}\end{array}$} & $\begin{array}{l}\text { Tujuan dan manfaat disampaikan dengan } \\
\text { jelas }\end{array}$ & 4 & \multirow{3}{*}{3,6} \\
\hline & & $\begin{array}{l}\text { Media sudah sesuai dengan kurikulum yang } \\
\text { berlaku }\end{array}$ & 4 & \\
\hline & & $\begin{array}{l}\text { Media harus relevan dengan materi yang } \\
\text { harus dipelajari siswa }\end{array}$ & 3 & \\
\hline \multirow{4}{*}{5} & \multirow{3}{*}{$\begin{array}{l}\text { Interaksi/ } \\
\text { Umpan } \\
\text { Balik }\end{array}$} & Media mudah diterima oleh siswa & 4 & \multirow{3}{*}{4,3} \\
\hline & & Pengguna tidak bosen menggunakan media & 4 & \\
\hline & & $\begin{array}{l}\text { Program Wondershare quiz creator menarik } \\
\text { sebagai pelatihan guru kreatif }\end{array}$ & 5 & \\
\hline & & Total Skor & 78 & \\
\hline
\end{tabular}

Berdasarkan data pada tabel 2, maka dapat dihitung persentase penilaian oleh ahli materi oleh Kemas. Badaruddin. Tingkat kevalidan $=\frac{78}{100} \times 100 \%=78 \%$.

Tabel interpretasi data validitas materi: $70 \%$ - 89\% Valid (dapat digunakan dengan revisi kecil). Pada angket yang terbuka masukan yang diberikan oleh ahli media yaitu 1) sumber item soal dan tabel pada pembuatan angket harus dicantumkan; 2) rumus perhitungan harus jelas; 3 ) suara pada musik 
kecil; 4) animasi video ditambahkan pada soal yang lain juga tidak hanya pada soal bahasa Inggris dan soal bahasa Arab; 5) soal kimia ada ganda sebaiknya diganti dengan soal mata pelajaran lain; dan 6) tertib dalam urutan pembuatan soal.

Tabel 3. Penilaian Hasil One to One Uji Kepraktisan

\begin{tabular}{|c|c|c|c|c|c|}
\hline \multirow{2}{*}{ No } & \multirow{2}{*}{ Indikator } & \multicolumn{2}{|c|}{ Skor } & \multicolumn{2}{|c|}{ Rata-rata } \\
\hline & & I & II & I & II \\
\hline \multicolumn{6}{|c|}{ A Kemudahan Penggunaan } \\
\hline 1 & $\begin{array}{l}\text { Penggunaan Wondershare quiz creator lebih } \\
\text { egektif dan efisien }\end{array}$ & 5 & 5 & \multirow{4}{*}{4,5} & \multirow{4}{*}{4,25} \\
\hline 2 & Buku pedoman WQC praktis digunakan & 5 & 4 & & \\
\hline 3 & $\begin{array}{l}\text { Program WQC dapat digunakan kapan saja } \\
\text { dan dimana saja sesuai dengan kebutuhan }\end{array}$ & 4 & 4 & & \\
\hline 4 & $\begin{array}{l}\text { Guru dapat belajar mandiri sesuai dengan } \\
\text { kemampuan belajarnya dengan menggunakan } \\
\text { program WQC }\end{array}$ & 4 & 4 & & \\
\hline \multicolumn{6}{|c|}{ B Model Pelatihan } \\
\hline 5 & $\begin{array}{l}\text { Kesesuaian model pelatihan dengan buku } \\
\text { pedoman }\end{array}$ & 4 & 5 & \multirow{3}{*}{4} & \multirow{3}{*}{4,33} \\
\hline 6 & Kejelasan deskripsi petunjuk penggunaan & 3 & 4 & & \\
\hline 7 & $\begin{array}{l}\text { Guru mengerti penjelasan instruktruk pada saat } \\
\text { pelatihan }\end{array}$ & 5 & 4 & & \\
\hline \multicolumn{6}{|c|}{ C Minat/motivasi } \\
\hline 8 & $\begin{array}{l}\text { membantu guru menjadi kreatif dalam } \\
\text { membuat soal yang bervariasi dengan berbagai } \\
\text { bentuk }\end{array}$ & 5 & 5 & \multirow{3}{*}{5} & \multirow{3}{*}{4,33} \\
\hline 9 & $\begin{array}{l}\text { Pengarahan sikap positif siswa terhadap materi } \\
\text { dan proses belajar dan evaluasi secara mandiri }\end{array}$ & 5 & 4 & & \\
\hline 10 & $\begin{array}{l}\text { Program WQC meningkatkan motivasi guru } \\
\text { dalam membuat ujian, kuis, ulangan bagi siswa }\end{array}$ & 5 & 4 & & \\
\hline \multicolumn{6}{|c|}{ D Daya Tarik } \\
\hline 11 & $\begin{array}{l}\text { Tampilan, warna, huruf dalam penyajian soal } \\
\text { tepat }\end{array}$ & 5 & 3 & \multirow{4}{*}{4,75} & \multirow{4}{*}{4,25} \\
\hline 12 & Tampilan animasi dan gambar menarik & 5 & 4 & & \\
\hline 13 & $\begin{array}{l}\text { Hasil kuis, ulangan, ujian langsung bisa diakses } \\
\text { siswa }\end{array}$ & 5 & 5 & & \\
\hline 14 & $\begin{array}{l}\text { Program WQC dapat digunakan dimanapun, } \\
\text { online ataupun offline }\end{array}$ & 4 & 5 & & \\
\hline \multicolumn{6}{|c|}{ E Proses Pengembangan } \\
\hline 15 & $\begin{array}{l}\text { Guru mampu membuat produk hasil } \\
\text { Wondershare quiz creator }\end{array}$ & 5 & 4 & \multirow{2}{*}{4,5} & \multirow{2}{*}{4,5} \\
\hline 16 & $\begin{array}{l}\text { Membantu proses kreativitas guru membuat } \\
\text { soal digital interaktif }\end{array}$ & 4 & 5 & & \\
\hline \multicolumn{6}{|c|}{ F Keberfungsian Dan Kegunaan } \\
\hline 17 & $\begin{array}{l}\text { program untuk memudahkan guru dalam } \\
\text { mengevaluasi hasil belajar siswa }\end{array}$ & 4 & 4 & \multirow[b]{2}{*}{4,5} & \multirow[b]{2}{*}{4,5} \\
\hline 18 & $\begin{array}{l}\text { Aplikasi WQC memudahkan guru dalam } \\
\text { mengoreksi hasil jawaban siswa secara cepat } \\
\text { dan efisien }\end{array}$ & 5 & 5 & & \\
\hline \multicolumn{6}{|c|}{ G Nilai Ekonomis } \\
\hline 19 & $\begin{array}{l}\text { Produk hasil WQC bernilai jual bagi guru } \\
\text { untuk bahan evaluasi belajar siswa secara } \\
\text { mandiri }\end{array}$ & 5 & 5 & \multirow[t]{2}{*}{5} & \multirow[t]{2}{*}{5} \\
\hline 20 & $\begin{array}{l}\text { Produk aplikasi WQC efisien dalam } \\
\text { menghemat kertas ulangan secara tradisional }\end{array}$ & 5 & 5 & & \\
\hline & Total Skor & 92 & 83 & & \\
\hline & Rata-rata & \multicolumn{2}{|c|}{87,5} & & \\
\hline
\end{tabular}

Berdasarkan data pada tabel 3, maka dapat dihitung persentase penilaian oleh kepraktisan informan ke I yaitu oleh kepala Madrasah Aliyah Patra Mandiri Palembang adalah sebagai berikut. Tingkat kepraktisan $=\frac{92}{100} \times 100 \%=92 \%$

Tabel 4. Penilaian Hasil Small Group Evaluation Uji Kepraktisan

\begin{tabular}{|c|c|c|c|c|c|c|}
\hline \multirow[b]{2}{*}{ No } & \multirow[b]{2}{*}{ Indikator } & \multicolumn{5}{|c|}{ Skor Penilaian } \\
\hline & & $\mathbf{I}$ & II & II & $\begin{array}{l}\mathbf{I} \\
\mathbf{V}\end{array}$ & $\mathbf{V}$ \\
\hline \multicolumn{7}{|c|}{ A Kemudahan Penggunaan } \\
\hline 1 & $\begin{array}{l}\text { Penggunaan Wondershare } \\
\text { quiz creator lebih egektif dan } \\
\text { efisien }\end{array}$ & 1 & 1 & 1 & 1 & 1 \\
\hline 2 & $\begin{array}{l}\text { Buku pedoman WQC praktis } \\
\text { digunakan }\end{array}$ & 1 & 1 & 1 & 1 & 1 \\
\hline 3 & $\begin{array}{l}\text { Program WQC dapat } \\
\text { digunakan kapan saja dan } \\
\text { dimana saja sesuai dengan } \\
\text { kebutuhan }\end{array}$ & 1 & 1 & 1 & 1 & 1 \\
\hline 4 & $\begin{array}{l}\text { Guru dapat belajar mandiri } \\
\text { sesuai dengan kemampuan } \\
\text { belajarnya dengan } \\
\text { menggunakan program } \\
\text { WQC }\end{array}$ & 1 & 1 & 1 & 0 & 1 \\
\hline \multicolumn{7}{|c|}{ B Model Pelatihan } \\
\hline 5 & $\begin{array}{l}\text { Kesesuaian model pelatihan } \\
\text { dengan buku pedoman }\end{array}$ & 1 & 1 & 1 & 1 & 1 \\
\hline 6 & $\begin{array}{l}\text { Kejelasan deskripsi petunjuk } \\
\text { penggunaan }\end{array}$ & 1 & 1 & 1 & 1 & 0 \\
\hline 7 & $\begin{array}{l}\text { Guru mengerti penjelasan } \\
\text { instruktruk pada saat } \\
\text { pelatihan }\end{array}$ & 1 & 1 & 1 & 1 & 1 \\
\hline \multicolumn{7}{|c|}{ C Minat/motivasi } \\
\hline 8 & $\begin{array}{l}\text { membantu guru menjadi } \\
\text { kreatif dalam membuat soal } \\
\text { yang bervariasi dengan } \\
\text { berbagai bentuk }\end{array}$ & 1 & 1 & 1 & 1 & 1 \\
\hline 9 & $\begin{array}{l}\text { Pengarahan sikap positif } \\
\text { siswa terhadap materi dan } \\
\text { proses belajar dan evaluasi } \\
\text { secara mandiri }\end{array}$ & 1 & 1 & 1 & 1 & 1 \\
\hline 10 & $\begin{array}{l}\text { Program WQC } \\
\text { meningkatkan motivasi guru } \\
\text { dalam membuat ujian, kuis, } \\
\text { ulangan bagi siswa }\end{array}$ & 1 & 1 & 1 & 1 & 1 \\
\hline \multicolumn{7}{|c|}{ D Daya Tarik } \\
\hline 11 & $\begin{array}{l}\text { Tampilan, warna, huruf } \\
\text { dalam penyajian soal tepat }\end{array}$ & 0 & 1 & 1 & 1 & 0 \\
\hline 12 & $\begin{array}{l}\text { Tampilan animasi dan } \\
\text { gambar menarik }\end{array}$ & 1 & 1 & 1 & 1 & 1 \\
\hline 13 & $\begin{array}{l}\text { Hasil kuis, ulangan, ujian } \\
\text { langsung bisa diakses siswa }\end{array}$ & 0 & 1 & 0 & 1 & 1 \\
\hline 14 & $\begin{array}{l}\text { Program WQC dapat } \\
\text { digunakan dimanapun, online } \\
\text { ataupun offline }\end{array}$ & 0 & 1 & 0 & 0 & 0 \\
\hline \multicolumn{7}{|c|}{ E Proses Pengembangan } \\
\hline 15 & $\begin{array}{l}\text { Guru mampu membuat } \\
\text { produk hasil Wondershare } \\
\text { quiz creator }\end{array}$ & 1 & 1 & 1 & 0 & 1 \\
\hline
\end{tabular}


Tiya Anggita, Abdullah Idi, Muhammad Fauzi

\begin{tabular}{|c|c|c|c|c|c|c|}
\hline 16 & $\begin{array}{l}\text { Membantu proses kreativitas } \\
\text { guru membuat soal digital } \\
\text { interaktif }\end{array}$ & 1 & 1 & 1 & 1 & 1 \\
\hline \multicolumn{7}{|c|}{ F Keberfungsian Dan Kegunaan } \\
\hline 17 & $\begin{array}{l}\text { program untuk memudahkan } \\
\text { guru dalam mengevaluasi } \\
\text { hasil belajar siswa }\end{array}$ & 1 & 1 & 1 & 1 & 1 \\
\hline 18 & $\begin{array}{l}\text { Aplikasi WQC memudahkan } \\
\text { guru dalam mengoreksi hasil } \\
\text { jawaban siswa secara cepat } \\
\text { dan efisien }\end{array}$ & 1 & 1 & 1 & 1 & 1 \\
\hline \multicolumn{7}{|c|}{ G Nilai Ekonomis } \\
\hline 19 & $\begin{array}{l}\text { Produk hasil WQC bernilai } \\
\text { jual bagi guru untuk bahan } \\
\text { evaluasi belajar siswa secara } \\
\text { mandiri }\end{array}$ & 1 & 1 & 1 & 1 & 1 \\
\hline 20 & $\begin{array}{l}\text { Produk aplikasi WQC efisien } \\
\text { dalam menghemat kertas } \\
\text { ulangan secara tradisional }\end{array}$ & 1 & 1 & 1 & 1 & 1 \\
\hline \multirow{2}{*}{\multicolumn{2}{|c|}{ Total Skor }} & 1 & 2 & 1 & 1 & 1 \\
\hline & & 7 & $\mathbf{0}$ & 8 & 7 & 7 \\
\hline \multirow{3}{*}{\multicolumn{2}{|c|}{ Persentase }} & 8 & 1 & 9 & 8 & 8 \\
\hline & & 5 & $\mathbf{0}$ & $\mathbf{0}$ & 5 & 5 \\
\hline & & $\%$ & $\begin{array}{l}0 \\
\%\end{array}$ & $\%$ & $\%$ & $\%$ \\
\hline & Rata-rata & \multicolumn{5}{|c|}{$89 \%$} \\
\hline
\end{tabular}

Berdasarkan data pada tabel 4, rumus yang digunakan untuk mengetahui persentase jawaban maka dihitung terlebih dahulu: nilai jawaban ya dengan skor 1 , nilai jawaban tidak dengan skor 0 , dikonversikan dalam bentuk persentase: Jawaban ya $=1 \times 100 \%$, Jawaban tidak $=0 \times 100 \%$.

Tabel 5. Perbandingan Sebelum dan Sesudah Melaksanakan Pelatihan

\begin{tabular}{cllc}
\hline $\begin{array}{c}\text { Pengetahuan } \\
\text { sebelum } \\
\text { mengikuti } \\
\text { pelatihan }\end{array}$ & \multicolumn{1}{c}{ Indikator Pertanyaan } & \multicolumn{1}{c}{$\begin{array}{c}\text { Pengetahuan } \\
\text { sesudah } \\
\text { mengikuti } \\
\text { pelatihan }\end{array}$} \\
\hline $91,25 \%$ & 1) & $\begin{array}{l}\text { Perubahan evaluasi tradisional (kertas pensil) } \\
\text { menjadi evaluasi digital (komputer) }\end{array}$ & $92,5 \%$ \\
\hline $1,25 \%$ & 2) & $\begin{array}{l}\text { Bapak/ Ibu mengetahui program } \\
\text { Wondershare quiz creator }\end{array}$ & $92,5 \%$ \\
\hline $2,5 \%$ & 3) & $\begin{array}{l}\text { Wonderhare Quiz Creator adalah Evaluasi } \\
\text { digital yang efisien, efektif untuk setiap mata } \\
\text { pelajaran }\end{array}$ & $93,75 \%$ \\
\hline $5 \%$ & 4) & $\begin{array}{l}\text { Pelatihan WQC membantu proses belajar } \\
\text { mandiri (mengulangi pelajaran) siswa di } \\
\text { rumah }\end{array}$ & $91,25 \%$ \\
\hline $3,75 \%$ & 5) & $\begin{array}{l}\text { Program WQC meningkatkan motivasi guru } \\
\text { dalam membuat ujian, kuis, ulangan bagi } \\
\text { siswa }\end{array}$ & $92,5 \%$ \\
\hline $3,75 \%$ & 6) & $\begin{array}{l}\text { Program WQC adalah program untuk } \\
\text { memudahkan guru dalam mengevaluasi hasil } \\
\text { belajar siswa }\end{array}$ & $92,5 \%$ \\
\hline $3,75 \%$ & 7) & $\begin{array}{l}\text { Tingkat pemahaman pesertapelatihan tentang } \\
\text { WQC baik dan mudah dipahami }\end{array}$ & $92,5 \%$ \\
\hline
\end{tabular}

\begin{tabular}{cclc}
\hline $2,5 \%$ & $8)$ & $\begin{array}{l}\text { Membantu proses kreativitas guru membuat } \\
\text { soal digital interaktif }\end{array}$ & $92,5 \%$ \\
\hline $1,25 \%$ & $9)$ & $\begin{array}{l}\text { Kejelasan deskripsi petunjuk penggunaan dan } \\
\text { penjelasan tetang program WQC }\end{array}$ & $90 \%$ \\
\hline $1,25 \%$ & $10)$ & $\begin{array}{l}\text { Tampilan program mudah dioperaksikan } \\
\text { (Suara jelas, tampilan jelas, gambar jelas) }\end{array}$ & $93,75 \%$ \\
\hline $2,5 \%$ & $11)$ & Tata letak huruf mudah dimengerti & $90 \%$ \\
\hline $2,5 \%$ & $12)$ & Animasi sesuai dengan tampilan soal & $88,75 \%$ \\
\hline $3,75 \%$ & $13)$ & $\begin{array}{l}\text { Guru mengerti penjelasan instruktruk pada } \\
\text { saat pelatihan }\end{array}$ & $90 \%$ \\
\hline $10 \%$ & $14)$ & $\begin{array}{l}\text { Guru kreatif dalam membuat tampilan soal/ } \\
\text { kuis interaktif }\end{array}$ & $92,5 \%$ \\
\hline $7,5 \%$ & $15)$ & $\begin{array}{l}\text { Guru sudah mampu membuat produk hasil } \\
\text { Wondershare quiz creator }\end{array}$ & $91,25 \%$ \\
\hline $9,5 \%$ & \multicolumn{1}{c}{ Rata-rata } \\
\hline
\end{tabular}

Berdasarkan tabel 5 tersebut terlihat bahwa pengetahuan sebelum mengikuti pelatihan rata-rata 9,5\% dan pengetahuan setelah mengikuti pelatihan adalah rata-rata $91,75 \%$. Untuk membuktikan signifikansi perbedaan pengetahuan sebelum dan sesudah mengikuti pelatihan, perlu diuji secara statistik dengan t-test berkorelasi (related). Untuk membuat keputusan tentang perbedaan signifikan atau tidak, maka harga t hitung perlu dibandingkan dengan harga $t$ tabel dengan dk n-2. Berdasarkan lampiran tabel II dalam nilai-nilai dalam distribusi t. berikut ini cara untuk membandingkan $t$ hitung dengan t tabel:

a. Tabel II dalam buku Sugiyono dengan $\mathrm{dk} n-2=$ 18.

b. Berdasarkan tabel tersebut, uji satu pihak dengan taraf 5\%, maka harga t tabel adalah 1,734 .

c. Jika harga $\mathrm{t}$ hitung jatuh pada daerah penerimaan Ha, maka Ha yang menyatakan bahwa pengetahuan sesudah pelatihan lebih baik bila dibandingkan dengan pengetahuan sebelum pelatihan.

d. Berdasarkan perhitungan bahwa $\mathrm{t}$ hitung adalah -1,302 jatuh pada penerimaan $\mathrm{Ha}$ atau penolakan Ho

Berikut ini adalah gambaran kurva perbedaan signifikan antara $t$ tabel dengan $t$ hitung. 
Pengembangan Model Pelatihan

Daerah penerimaan $\mathrm{Ha}$

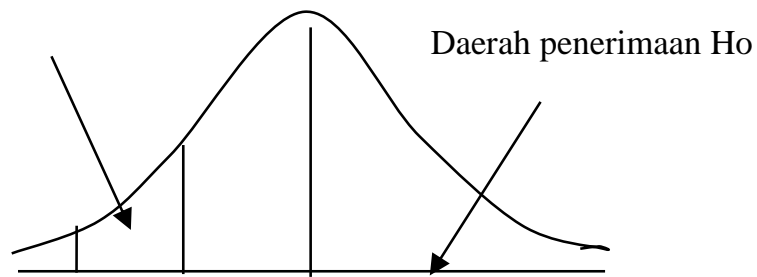

$-1,302$

1,734

Gambar 1. Uji Hipotesis perbedaan t tabel dengan t hitung

Dengan demikian berdasarkan perhitungan di atas, maka dapat disimpulkan bahwa terdapat perbedaan yang signifikan antara sebelum dan sesudah guru mengikuti pelatihan berbasis aplikasi wondershare quiz creator.

Evaluasi tanggapan (reaksi) bertujuan untuk mengetahui tingkat kepuasan peserta pelatihan terhadap penyelenggaraan pelatihan yang diikuti (Nurhayati, 2018). Program dianggap berhasil jika guru sebagai peserta pelatihan merasa puas terhadap model pelatihan. Peneliti menggunakan angket untuk mengukur evaluasi tanggapan atau reaksi.

Tabel 6. Penilaian Hasil Reaksi/Tanggapan guru terhadap pelatihan

\begin{tabular}{|c|c|c|c|c|c|c|c|c|c|}
\hline \multirow[b]{2}{*}{ No } & \multirow[b]{2}{*}{ Nama Guru } & \multicolumn{6}{|c|}{ Item Pertanyaan } & \multirow{2}{*}{$\begin{array}{l}\text { Sk } \\
\text { or }\end{array}$} & \multirow{2}{*}{$\begin{array}{l}\text { Persenta } \\
\text { se }\end{array}$} \\
\hline & & P1 & $\mathrm{P} 2$ & $\begin{array}{l}\mathrm{P} \\
3\end{array}$ & $\mathrm{P} 4$ & $\begin{array}{l}\mathrm{P} \\
5\end{array}$ & P6 & & \\
\hline 1 & Runaila & 3 & 3 & 3 & 5 & 5 & 3 & 22 & $73,3 \%$ \\
\hline 2 & $\begin{array}{l}\text { Eka } \\
\text { Sulistiowati }\end{array}$ & 3 & 3 & 4 & 5 & 5 & 3 & 23 & $76,6 \%$ \\
\hline 3 & Izzati & 4 & 3 & 4 & 5 & 5 & 3 & 24 & $80 \%$ \\
\hline 4 & Kartini & 3 & 3 & 4 & 5 & 5 & 4 & 24 & $80 \%$ \\
\hline 5 & Yuli Hartati & 4 & 3 & 4 & 5 & 5 & 4 & 25 & $83,3 \%$ \\
\hline 6 & Setilawati & 3 & 3 & 4 & 5 & 5 & 4 & 24 & $80 \%$ \\
\hline 7 & Pepi Aprianti & 4 & 3 & 4 & 5 & 5 & 3 & 24 & $80 \%$ \\
\hline 8 & Anggi Septian & 4 & 3 & 4 & 5 & 5 & 4 & 25 & $83,3 \%$ \\
\hline 9 & $\begin{array}{l}\text { Laras } \\
\text { Pebrianti }\end{array}$ & 4 & 3 & 3 & 5 & 5 & 3 & 23 & $76,6 \%$ \\
\hline 10 & Adharul Fajri & 4 & 3 & 3 & 5 & 5 & 3 & 23 & $76,6 \%$ \\
\hline 11 & Kasmuyadi & 2 & 3 & 4 & 5 & 5 & 4 & 23 & $76,6 \%$ \\
\hline 12 & Paisar & 4 & 4 & 4 & 5 & 5 & 3 & 25 & $83,3 \%$ \\
\hline 13 & Ali Akbar & 4 & 4 & 4 & 5 & 5 & 4 & 26 & $86,6 \%$ \\
\hline
\end{tabular}

Intizar - Vol. 27 No. 1 (2021)

\begin{tabular}{llllllllll}
\hline 14 & Rofiko & 3 & 4 & 3 & 5 & 5 & 3 & 23 & $76,6 \%$ \\
\hline 15 & Okta Trisandi & 3 & 4 & 3 & 5 & 5 & 4 & 24 & $80 \%$ \\
\hline 16 & Emieliza & 4 & 4 & 4 & 5 & 5 & 4 & 26 & $86,6 \%$ \\
\hline 17 & Elyana & 4 & 4 & 4 & 5 & 5 & 4 & 26 & $86,6 \%$ \\
\hline 18 & Fauziah & 3 & 4 & 3 & 5 & 5 & 3 & 23 & $76,6 \%$ \\
\hline 19 & Menori & 3 & 4 & 4 & 5 & 5 & 3 & 24 & $80 \%$ \\
\hline 20 & Yana & 3 & 4 & 4 & 5 & 5 & 3 & 24 & $80 \%$ \\
\hline & Total & 69 & 69 & 7 & 10 & 1 & 69 & 48 & 1602,60 \\
& & & & 4 & 0 & 0 & & 1 & $\%$ \\
\hline & Rata-rata & 3 & 3 & 4 & 5 & 5 & 3 & 24 & $80 \%$
\end{tabular}

Berdasarkan data pada tabel 6, maka dapat dihitung persentase evaluasi reaksi (tanggapan) terhdap model pelatihan guru berbasis aplikasi wondershare quiz creator di Madrasah Aliyah Patra Mandiri Palembang adalah menggunakan rumus sebagai berikut.

Evaluasi reaksi $=\frac{\text { Skor } \text { Total }}{\text { Skor } \text { Maksimal }} \times 100 \%$

Berdasarkan indikator pedoman observasi tersbut, maka diperoleh tabel sebagai berikut.

Tabel 7. Penilaian Hasil Observasi pada saat Pelatihan

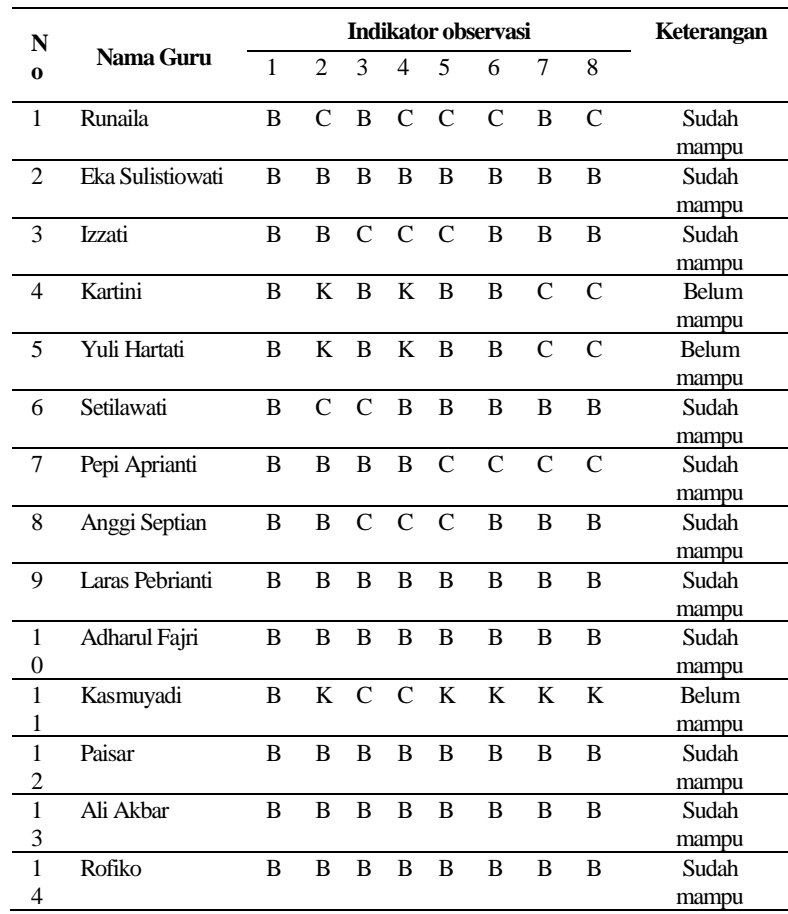


Tiya Anggita, Abdullah Idi, Muhammad Fauzi

\begin{tabular}{llccccccccc}
\hline 1 & Okta Trisandi & B & B & B & B & B & B & B & B & $\begin{array}{c}\text { Sudah } \\
\text { mampu }\end{array}$ \\
\hline 1 & Emieliza & B & K & C & C & K & K & K & K & $\begin{array}{c}\text { Belum } \\
\text { mampu }\end{array}$ \\
\hline 6 & Elyana & B & B & B & B & B & B & B & B & $\begin{array}{c}\text { Sudah } \\
\text { mampu }\end{array}$ \\
\hline 7 & Fauziah & B & B & C & C & C & B & B & K & $\begin{array}{c}\text { belum } \\
\text { mampu }\end{array}$ \\
\hline 1 & & & & & & & & & & B \\
\hline 1 & Menori & B & B & B & B & B & B & B & B & $\begin{array}{c}\text { Sudah } \\
\text { mampu }\end{array}$ \\
\hline 9 & & & & & & & & & & Bandah \\
\hline 2 & Yana & B & B & B & B & B & B & B & B & $\begin{array}{c}\text { Sudampu } \\
\text { mampu }\end{array}$ \\
\hline
\end{tabular}

Berdasarkan data pada tabel 7, maka dapat dilihat evaluasi hasil dengan menggunakan pedoman observasi terhadap model pelatihan guru berbasis aplikasi wondershare quiz creator di Madrasah Aliyah Patra Mandiri Palembang adalah terdapat lima orang guru yang belum berhasil membuat CD Interatif berbasis aplikasi wondershare quiz creator.

\section{Analisis/Diskusi}

\section{Tahap Perencanaan Penelitian}

Perencanaan penelitian adalah kegiatan untuk menetapkan analisis potensi masalah, rumusan tujuan, rancangan pelatihan. Langkah pengkajian potensi. Masalah, kebutuhan pelatihan, perumusan tujuan pelatihan, dan merancang program pelatihan adalah langkah langkah yang termasuk ke dalam tahap perencanaan.

\section{Tahap Pengembangan}

Tahap pengembangan terdiri dari dua yaitu validasi ahli dan uji kepraktisan. Validasi produk dilakukan oleh para ahli (expert review), adalah proses kegiatan menilai desain produk awal/prototipe I yang dihasilkan secara rasional dengan indikasi sudah tepat atau belum (Febriyanti, 2019). Validasi desain dalam penelitian ini dilakukan oleh dosen ahli manajemen pelatihan guru atau pedagogik atau ahli materi untuk mendapat masukan tentang desian model yang dibuat peneliti. Validasi kedua dilakukan oleh dosen ahli media untuk mendapatkan masukan tentang kelebihan dan kekurangan produk yang dihasilkan melalui lembar lampiran validasi. Hasil validasi dimanfaatkan untuk memperbaiki design produk awal (prototipe I). Masukan dari ahli dan praktisi dalam tahap validasi desain produk kemudian dijadikan pertimbangan untuk melakukan kegiatan revisi desain produk. Pada tahap uji ahli ini adalah bertujuan untuk mengetahui kelayakan pengembangan model pelatihan guru kreatif beserta paket pelatihan dapat digunakan oleh instruktur dan peserta.

Validasi ahli media dilakukan oleh Fuad Abdul Rachman, pada tanggal 2 Maret 2021 di kediaman rumahnya. Tingkat kevalidan adalah $78 \%$. Sehingga berdasarkan tabel interpretasi adalah $70 \%$ - 89\% Valid (dapat digunakan dengan revisi kecil). Sedangkan validasi materi atau pedagogik atau manjemen pelatihan dilakukan oleh Kemas. Badaruddin selaku dosen ahli manajemen. Validator dilakukan di lokasi UIN Raden Fatah Palembang pada tanggal 15 Februari 2021. Tingkat kevalidan adalah $78 \%$, dengan tabel interpretasi data validitas materi: $70 \%$ - 89\% Valid (dapat digunakan dengan revisi kecil). Uji kepraktisan dilaksanakan dua tahap yaitu uji kepraktisan one to one dan uji kepraktisan small group evaluation. Berdasarkan analisis perhitungan, uji kepraktisan pada tahap one to one evaluation rata-rata adalah $87,5 \%$. Sehingga dapat disimpulkan praktis digunakan dengan revisi. berdasarkan analisis perhitungan uji kepraktisan tahap small group adalah $89 \%$. Sehingga dapat disimpulkan praktis digunakan dengan revisi.

\section{Tahap Uji Coba (Efektifitas Model)}

Hasil dari uji efektivitas bahwa t hitung adalah -1,302 jatuh pada penerimaan $\mathrm{Ha}$ atau penolakan Ho. Sedangkan uji satu pihak dengan taraf 5\%, maka harga $t$ tabel pada buku Sugiyono adalah 1,734. Jadi, berdasarkan perbedaan yang 
signifikan sebelum dan sesudah pelatihan, maka dapat disimpulkan bahwa Aplikasi wondershare quiz creator efektif untuk meningkatkan kreativitas guru di Madrasah Aliyah Patra Mandiri Palembang.

Untuk mengetahui keefektifan model pelatihan dilakukan dengan uji coba lapangan. Dalam pelaksanaan pelatihan dibagi menjadi tiga tahap yaitu tahap pembuka pelatihan, inti pelatihan, dan penutup pelatihan.

\section{a. Kegiatan Pembuka Pelatihan (Persiapan)}

Kegiatan pembuka pelatihan guru diawali dengan pembukaan resmi dari kepala Madrasah, kemudian dilanjutkan dengan apersepsi, motivasi dan tujuan pelatihan serta dijelaskan hal-hal yang terkait dengan pelaksanaan pelatihan sesuai dengan yang tertulis dalam buku panduan atau pedoman pelatihan. Pada tahap ini juga dilakukan pembagian kelompok antara peserta pelatihan dengan teman yang telah melaksanakan pelatihan uji coba Small Group Evaluation. Penjelasan tentang tata kerja kelompok dan pendampingan serta target pelatihan juga disampaikan pada tahap ini. Sebelum memasuki kegiatan inti, peserta pelatihan dibagikan anget sebelum dan sesudah untuk mengetahui keberhasilan kegiatan pelatihan.

b. Kegiatan Inti (Penyampaian Materi)

Kegiatan inti adalah kegiatan menyampaikan materi pelatihan yaitu mengenai aplikasi wondershare quiz creator. Materi disampaikan oleh peneliti tesis sebagai narasumber atau trainer. Pada dasarnya kegiatan inti yaitu penyampaian materi aplikasi wondershare quiz creator (praktik), dan penugasan pembuatan kuis interaktif pada peserta pelatihan. Strategi yang digunakan dalam pelatihan ini adalah teknik berantai Snowball. Teknik ini diwujudkan dengan adanya pengelompokan dari uji coba Small group evaluation sebanyak 5 orang guru, masing-masing guru tersembut melakukan pendampingan kepada 4 orang guru. Kerjasama diwujudkan dalam bentuk diskusi, sharing of experience, pembagian kerja, pemecahan masalah untuk mencapai tujuan bersama yaitu meningkatkan kreativitas guru dalam membuat soal interaktif berbasis teknologi. Pendampingan intensif dilakukan oleh narasumber kepada peserta pelatihan yang belum mencapai keberhasilan dan untuk mempermudah pencapaian tujuan dalam kegiatan pelatihan. Tujuan yang ingin dicapai adalah peserta pelatihan dapat meningkatkan kreativitas dalam membuat soal interaktif berbasis aplikasi wondershare quiz creator.

\section{c. Kegiatan Penutup}

Kegiatan penutup adalah kegiatan akhir pelatihan. dalam kegiatan ini narasumber memberikan refleksi pelatihan, pemberian kesimpulan, pemberian pesan, motivasi, dan membahas rencana tindak lanjut.

\section{Tahap Evaluasi}

Tahap evaluasi untuk mengukur efektivitas model pelatihan yang dikembangkan yaitu dengan istilah teknik berantai Snowball. Model evaluasi program yang khusus diciptakan untuk mengetahui keberhasilan pelaksanaan diklat adalah model evaluasi Kirkpatrrick. "The fourlevel evaluation" is reaction, learning, behavior and results. Peneliti hanya menggunakan tiga tahap yaitu evaluasi tanggapan, evaluasi pembelajaran, dan evaluasi hasil.

Evaluasi pembelajaran dilihat dari uji efektivitas. Pada level ini, peserta diklat mempelajari pengetahuan atau keterampilan yang disampaikan dalam kegiatan pembelajaran (Nurhayati, 2018). peneliti menggunakan angket untuk membandingkan antara pengetahuan peserta mengenai pelatihan tersebut sebelum dan sesudah 
mengikuti pelatihan (pre test dan post test). Instrumen angket yang digunakan adalah rating scale untuk tes awal dan akhir yang terdiri dari 15 pertanyaan. Peserta pelatihan memberikan centang arti setiap angka adalah sebagai berikut: angka 0 jika bila sama sekali belum tahu, angka 1jika telah mengetahui sampai dengan $25 \%$, angka 2 jika telah mengetahui sampai dengan $50 \%$, angka 3jika telah mengetahui sampai dengan $75 \%$, angka 4 jika telah mengetahui $100 \%$ (semuanya).

Evaluasi hasil dilihat dari keberhasilan guru membuat cd interatktif bersisi soal kuis sebagai bukti bahwa kompetensi mereka yang berkaitan dengan kreativitas untuk melakukan praktik pelatihan telah meningkat. Evaluasi hasil pada tesis ini menggunakan angket pedoman observasi. Setelah pelatihan, masing-masing kelompok mengumpulkan hasil karya yaitu $\mathrm{CD}$ interaktif yang telah dibuat bukti bahwa mereka telah mengikuti kegiatan pelatihan dengan baik.

Evaluasi tanggapan berisi tentang tanggapan guru terhadap pelatihan yang dilaksanakan. Evaluasi Tanggapan (reaksi) bertujuan untuk mengetahui tingkat kepuasan peserta pelatihan terhadap penyelenggaraan pelatihan yang diikuti (Nurhayati, 2018). Aspek indikator angket dari penyelenggaraaan dalam penelitian ini meliputi: ketercapaian tujuan pelatihan, strategi dan metode yang digunakan dalam pelatihan, narasumber, perangkat pelatihan, sarana dan prasarana yang mendukung, dan evaluasi yang digunakan. Berdasarkan analisis perhitungan di atas, evaluasi reaksi (tanggapan) pelatihan guru rata-rata adalah $80 \%$.

\section{Kesimpulan}

Terdapat perbedaan yang signifikan antara sebelum dan sesudah guru mengikuti pelatihan berbasis aplikasi wondershare quiz creator. Hal ini dapat disimpulkan bahwa model pelatihan berbasis aplikasi wondershare quiz creator efektif untuk meningkatkan kreatifitas guru Madrasah Aliyah Patra Mandiri Palembang untuk membuat soal interaktif.

\section{Daftar Pustaka}

Anundiati, I., \& Fauzi, M. F. (2015). E-learning Pembelajaran Bahasa Arab. Universitas Muhammadiyah Malang.

Febriyanti. (2019). Pengembangan Bahan Ajar Pembelajaran Tematik Berbasis Multiple Inteligences Tema Pengalamanku Kelas 1 Di Madrasah Ibtidaiyah Negeri 1 .... http://repository.radenfatah.ac.id/id/eprint/38 06

Janssen, E. M., Meulendijks, W., Mainhard, T., Verkoeijen, P. P. J. L., Heijltjes, A. E. G., van Peppen, L. M., \& van Gog, T. (2019). Identifying characteristics associated with higher education teachers' Cognitive Reflection Test performance and their attitudes towards teaching critical thinking. In Teaching and Teacher Education (Vol. 84). Teaching and Teacher Education. https://doi.org/10.1016/j.tate.2019.05.008

Meryansumayeka, M., \& Aisyah, N. (2016). Pendesainan Pembelajaran Menggunakan Pendekatan Analisis Nilai Pada Mata Kuliah Telaah Kurikulum. In Jurnal Pendidikan Matematika (Vol. 7, Issue 1). Jurnal Pendidikan Matematika. https://doi.org/10.22342/jpm.7.1.4091.

Nurhayati, Y. (2018). Penerapan Model Kirkpatrick untuk Evaluasi Program Diklat Teknis Subtantif Materi Perencanaan Pembelajaran Di Wilayah Kerja Provinsi Kepulauan Riau. In Andragogi: Jurnal Diklat Teknis Pendidikan dan Keagamaan (Vol. 6, Issue 2, pp. 170-187). https://doi.org/10.36052/andragogi.v6i2.63

Oliver, B., Tucker, B., Gupta, R., \& Yeo, S. (2008). Evaluate: An evaluation instrument for measuring students' perceptions of their engagement and learning outcomes. Assessment and Evaluation in Higher Education, 33(6), 619-630. https://doi.org/10.1080/02602930701773034

Penyusun, T. (2003). Undang-undang Republik Indonesia nomor 20 tahun 2003 tentang 
sistem pendidikan nasional. Pemerintah Republik Indonesia.

Penyusun, T. (2007). Permendiknas Nomor 16 tahun 2007 Tentang Kualifikasi Akademik Dan Kompetensi profesional Guru.

Permendikbud. (2014). Permendikbud Nomor 104 Tahun 2014 Tentang Penilaian Hasil Belajar. In Kementrian Pendidikan dan Kebudayaan RI (pp. 1-8). https://luk.staff.ugm.ac.id/atur/bsnp/Permendi kbud104-2014PenilaianHasilBelajar.pdf

Sangkala, I., \& ul Haq, M. Z. (2019). Wondershare quiz creator Software Improves Students' Reading Comprehension at the English Education Class. SSRN Electronic Journal, 1(2). https://doi.org/10.2139/ssrn.3346900

Siti, K., \& Paulus, H. (2019). Development of Wondershare quiz creator Multiple Choice Evaluation Tools in Economic Mathematics. International Journal of Engineering \& Technology, 7(4.11). https://doi.org/10.2991/icesre-18.2019.64

van den Berg, G. (2004). The use of assessment in the development of higher-order thinking skills. Africa Education Review, 1(2), 279294.

https://doi.org/10.1080/18146620408566285 